\title{
Eco Tools for Urban Waste Management in India
}

\author{
V.P. Upadhyay, M.Rajeswar Prasad*, Ajay Srivastav* and Khazan Singh \\ Ministry of Environment and Forests, North Eastern Regional Office, \\ Shillong 793003 , Meghalaya, India \\ *Ministry of Environment and Forests, Eastern Regional office, \\ Bhubaneswar 751 023, Orissa, India
}

KEYWORDS Biodegradable Component. Disposal Site. Incineration Systems. Landfills. Solid Waste Management

\begin{abstract}
The population growth has put tremendous pressure on the quality of Environment of urban life. The residents generate various kinds of wastes of biodegradable and non biodegradable categories. The impact created by these wastes on the environment is enormous, if proper disposal and management options are not applied. The waste could become a resource and the society can benefit from these wastes with proper collection and disposal technologies. Majority of wastes can be recycled and the recycling technologies available today world wide has a promising employment and energy generating options. The sanitary landfills, biogas generating technologies, vermi- composting, incineration, municipal solid waste combustion technologies offer good incentives for the local bodies and the governments to derive benefits by utilizing the wastes. The present paper highlights the present scenario of waste management and the options available to convert these wastes into useful products.
\end{abstract}

\section{INTRODUCTION}

The urban population has grown at a rate of $19.90 \%-34.61 \%$ during last two decades whereas the growth rate of total population is about $2 \%$. The urban population is increasing at a rate of $3-4 \%$ and the rural at a rate of $1-1.5 \%$. As per 1991 census, the total number of urban centres has increased from 3301 in 1981 to 3768 (with a population of 217 million people) whereas number of cities increased from 218 to 291. Number of metropolitan cities (inhabiting population more than 1 million) has increased almost two fold i.e. from 12 in 1981 to more than 30 in 1991 accounting for about half of the total urban population in India. The cities of Bombay, Kolkata, Delhi and Chennai together accommodate 37.22 million populations. One of the main reasons for increase in the urbanization is the migration of rural population into the towns/cities/metropolitan cities for the employment. Urban population (26\%) generates $40 \%$ of the National Domestic Product (NDP) due to better educational, medical and other infrastructural facilities.

Unprecedented growth in population of urban areas and more particularly in metropolitan cities/class-I cities have put tremendous pressure on some of the basic aspects of quality of life

For correspondence: V.P. Upadhyay, Ministry of Environment and Forests, North Eastern Regional Officer, Shilong 793003 Meghalaya, India

Fax: 0364-2227673; E-mail: vpupadhyaya@hotmail.com such as housing, water and power supply and water and air quality resulting in deterioration of environmental quality. The solid waste generated in these urban areas is of major concern. Solid waste, in general, can be classified into three categories (Table 1). Rapid population growth, urbanization and industrial growth have led to severe problems of waste management in urban centres. To keep the streets clean, collection of garbage from public places and to ensure its safe disposal, fairly large number of employees are engaged by concerned organizations. Yet, only about half to two-thirds of the waste generated is collected with present system.

Each of the urban residents generates 350 to $1000 \mathrm{~g}$ solid waste every day. Taking waste from commercial and industrial establishments, the total waste generation/day adds up to an enormous quantity. The quantity of municipal solid wastes in a few important cities is given in Table 2. With increasing population and rising income, the lifestyle of urban residents is also changing. Urban India is thus becoming a "throw -away society". The wastes in bigger cities are generally paper, plastic, metal and hazardous materials apart from vegetable wastes. Biodegradable household waste has far less impact than the waste generated by activities like manufacturing of goods. The industrialization and high level of affluence influence the composition and quantity of waste. 73 to $96 \%$ of the typical family's waste comprises biodegradable materials in the lower income 
Table 1: Categories of solid wastes.

\begin{tabular}{|c|c|c|}
\hline Category & Sources of generation & Types of solid wastes \\
\hline Municipal Solid Wastes & $\begin{array}{l}\text { Residential - } \\
\text { family dwellings, low, medium \& high- } \\
\text { rise buildings/apartments, etc. } \\
\text { Commercial - } \\
\text { stores, restaurants, markets, hotels, } \\
\text { shopping complexes, repair workshop } \\
\text { shops, etc. } \\
\text { Open areas - } \\
\text { Streets, alleys, parks, vacant plots, play- } \\
\text { grounds, beaches, highways, recreational areas, etc. } \\
\text { Treatment plant sites- } \\
\text { Water, wastewater \& industrial treatment processes, e }\end{array}$ & $\begin{array}{l}\text { Food wastes, rubbish, } \\
\text { ashes, special wastes } \\
\text { Food wastes, rubbish, } \\
\text { ashes, construction. } \\
\text { Wastes, special wastes, } \\
\text { Occasionally hazardous Wastes } \\
\text {. } \\
\text { Special wastes, rubbish } \\
\text { Treated wastes /residual sludges. }\end{array}$ \\
\hline Industrial Wastes & $\begin{array}{l}\text { Textiles, paper \& allied products, } \\
\text { chemicals \& related products, rubber, food \& kindred } \\
\text { products, furniture, printing, leather \& leather products, } \\
\text { glass, Petroleum \& refineries, etc. }\end{array}$ & $\begin{array}{l}\text { Chemicals, metals, scrap } \\
\text { products, gypsum, asbestos } \\
\text { resins, glass, organic dyes, } \\
\text { glues, ect. }\end{array}$ \\
\hline Hazardous Wastes & $\begin{array}{l}\text { Industries - } \\
\quad \text { Chemical \& oil refineries, ordinance } \\
\quad \text { factories, fire works, etc. } \\
\text { Hospitals : } \\
\quad \text { Bio-medical wastes }\end{array}$ & $\begin{array}{l}\text { Volatile organic chemicals, } \\
\text { inflammable substances, } \\
\text { toxic gases \& liquids, etc. } \\
\text { Chemicals, pathological } \\
\text { wastes, infectious wastes, } \\
\text { sharp objects, pharmaceutical } \\
\text { wastes, Laboratory wastes, } \\
\text { pressurized cans, etc. }\end{array}$ \\
\hline
\end{tabular}

Table 2: Municipal solid waste generation and collection in major Indian cities based on data for the year 1994

\begin{tabular}{lccc}
\hline City & $\begin{array}{c}\text { Generated } \\
\text { (tonnes/day) }\end{array}$ & $\begin{array}{c}\text { Cleared } \\
\text { (tonnes/day }\end{array}$ & $\%$ Collected \\
\hline Ahmedabad & 1500 & 1200 & 80 \\
Bangalore & 2130 & 1800 & 85 \\
Mumbai & 5800 & 5000 & 86 \\
Kolkata & 3500 & 3150 & 90 \\
Delhi & 3880 & 2420 & 62 \\
Lucknow & 1500 & 1000 & 67 \\
Chennai & 2675 & 2140 & 80 \\
Patna & 1000 & 300 & 30 \\
Surat & 1250 & 1000 & 80 \\
\hline
\end{tabular}

groups while in higher income groups the figure is only about $26 \%$. There exists a direct link between affluence and municipal waste. There has been increase in the Gross Domestic Product (GDP) in countries of Organization for Economic Cooperation and Development (OECD) by $40 \%$ with similar increase in municipal wastes (Table 3). With this link between waste generation and GDP continuing, more effort shall be required in managing the urban solid wastes.

Management of solid waste requires proper system of daily collection, transportation and disposal. The knowledge of composition of wastes, their method of collection and disposal, recycling of waste and energy generation from wastes, shall help convert them to useful products. Solid waste management requires commitment, resources, and involvement of the community and private entrepreneurs to work with local governments.

\section{THE URBAN SOLID WASTES}

Present State: The characteristics of waste depend on various factors like food habits, cultural traditions of the inhabitants, lifestyles, climate, etc. The Table 4 and 5 present the changes in the characteristics of waste in the last two decades (Bhide and Sundaresan, 1983; TERI, 1998). It is inferred that changes in the relative shares of different constituents of waste in the past several decades are due to the changing lifestyles and increasing consumerism.

Collection: Waste is usually collected in houses in small bins and is then transferred to community bins either by those who generate it or by private or municipal workers. Waste from community bins is collected by trucks and carried to the disposal site. It takes anywhere from 3 to 
Table 3: OECD example of how development is intricately linked to increase in waste levels.

\begin{tabular}{|c|c|c|c|c|c|}
\hline $\begin{array}{l}\text { OECD } \\
\text { Countries }\end{array}$ & $\begin{array}{c}\text { Municipal } \\
\text { waste (kilos per } \\
\text { capita) }\end{array}$ & $\begin{array}{l}\text { Number of } \\
\text { household }\end{array}$ & $\begin{array}{l}\text { Recycled } \\
\text { (per cent) }\end{array}$ & $\begin{array}{c}\text { Incinerated } \\
\text { (per cent) }\end{array}$ & $\begin{array}{l}\text { Landfilled } \\
\text { (per cent) }\end{array}$ \\
\hline Australia & 690 & 400 & id & id & Id \\
\hline Canada & 630 & 310 & 19 & 6 & 75 \\
\hline Denmark & 530 & 500 & 23 & 54 & 23 \\
\hline France & 560 & 410 & 9 & 32 & 59 \\
\hline Hungary & 420 & 270 & - & 7 & 93 \\
\hline Ireland & 430 & 290 & 8 & - & 92 \\
\hline Italy & 470 & 400 & - & 6 & 94 \\
\hline Japan & 400 & Id & 4 & 69 & 27 \\
\hline Portugal & 350 & Id & 12 & - & 88 \\
\hline Sweden & 440 & 360 & 19 & 42 & 39 \\
\hline UK & 490 & 460 & 7 & 10 & 83 \\
\hline USA & 720 & Id & 27 & 16 & 57 \\
\hline
\end{tabular}

Note: id-insufficient data

Source: OECD (Reproduced)

Table 4: Characteristics of municipal solid waste (TERI, 1998 ).

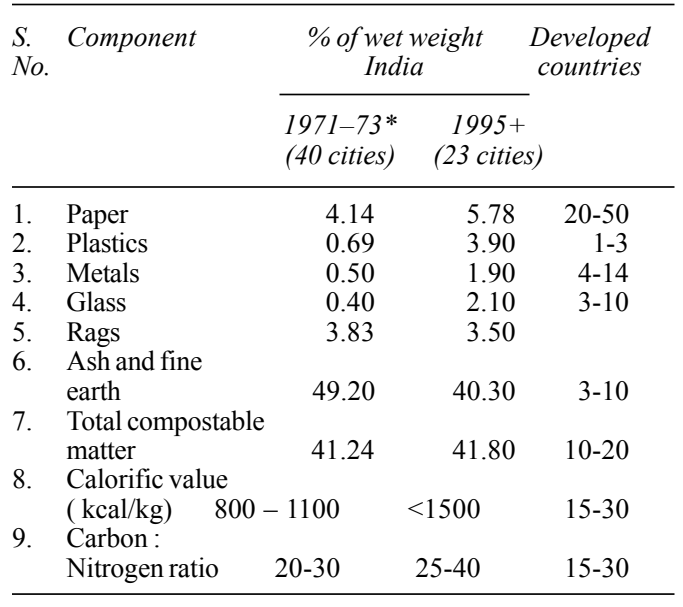

Table 5: The constituents (\%) of municipal solid wastes.

\begin{tabular}{lc}
\hline Component & Composition \\
\hline Vegetable/leaves & 40.15 \\
Paper & 3.8 \\
Plastics & 0.81 \\
Leather/rubber & 0.62 \\
Glass/Ceramic & 0.44 \\
Metal & 0.64 \\
Stones/ashes/dust & 41.81 \\
Miscellaneous & 11.73 \\
\hline
\end{tabular}

7 days to reach the destination site of disposal. The collection, transportation and disposal of waste are labour intensive activities as modern systems are not used. In recent years, the number of cities that are short of municipal workers, has increased (Table 6) as a result less than three-

fourths of the waste is only collected as shown in Table 7 (Bhide and Sundaresan, 1983, NIUA, 1989).

Table 6: Manpower for solid waste management.

\begin{tabular}{|c|c|c|}
\hline \multirow{2}{*}{$\begin{array}{l}\text { No. of workers / } \\
\text { Million } \\
\text { polulation }\end{array}$} & \multicolumn{2}{|c|}{ Cities (\%) } \\
\hline & 1971(40 cities $*)$ & 1989 (155 cities) \\
\hline$<1000$ & NA & 56.1 \\
\hline $1000-2000$ & 47.5 & 25.2 \\
\hline $2000-3000$ & 27.5 & 11.0 \\
\hline $3000-4000$ & 18.5 & 5.2 \\
\hline $4000-5000$ & 7.5 & 1.3 \\
\hline$>5000$ & - & 1.3 \\
\hline
\end{tabular}

Table 7: Collection efficiency of municipalities based on NIUA (1989).

\begin{tabular}{lccc}
\hline $\begin{array}{l}\text { Class population } \\
\text { of city }\end{array}$ & $\begin{array}{c}\text { No.of urban } \\
\text { centres } \\
\text { responded }\end{array}$ & $\begin{array}{c}\text { Waste } \\
\text { collected (\%) }\end{array}$ \\
\hline 1 & 100000 or more & 98 & 71.9 \\
2 & 50000 to 99999 & 27 & 66.5 \\
3 & 20000 to 49999 & 13 & 76.9 \\
4 & 10000 to 19999 & 7 & 82.5 \\
5 & 5000 to 9999 & 2 & 69.1 \\
6 & less than 5000 & 153 & 72.5 \\
\hline
\end{tabular}

Transportation: The open trucks, compaction vehicles, tractor-trailers, and carriercontainers are usually used for transporting the solid wastes. However, open trucks and tractor trolleys are used by most of the municipalities in small towns. Bullock carts and hand trolleys are also in use in many small towns. The vehicles are normally owned and maintained by local bodies viz; municipalities/town area committees 
Table 8: Transport capacity to carry municipal solid waste (Bhoyar et al., 1996)

\begin{tabular}{lc}
\hline $\begin{array}{l}\text { Capacity } \\
\text { (cubic metres/million population) }\end{array}$ & $\begin{array}{c}\text { Cities (\%) } \\
\text { ( } 44 \text { cities })\end{array}$ \\
\hline$<100$ & 4.5 \\
$100-200$ & 34.1 \\
$200-300$ & 29.6 \\
$300-400$ & 25.0 \\
$>400$ & 6.8 \\
\hline
\end{tabular}

etc. The whole system of handling and disposal of urban wastes is now being awarded to private contractors by many local bodies. This system may come out to be cost effective and efficient and monitoring shall make them more accountable for the services rendered by them. The privatization of urban waste management system could be efficient and profitable ventures. A cubic metre of MSW at the generation site weighs about $500 \mathrm{~kg}$ (Bhide and Sundaresan, 1983). Considering the daily per capita generation rate of $480 \mathrm{gm}$ waste, total volume required to be transported is about 960 cubic metres per million populations. The transport capacity required is about 320 cubic metres per million population / day. The available transport capacities in 44 Indian cities (Table 8) indicate that about $70 \%$ of Indian cities do not have required capacity for transportation. The above estimate may rise further keeping in view the age of the transport vehicle employed by municipal authorities in large number of towns. The wastes, not collected find its way into sewers or eaten by cattle or burnt in the open by the sweepers. The biodegradable wastes lying in vacant areas in colonies and along the road pollute the local environment due to faster decomposition. The non-biodegradable wastes, which pose major health hazard and environ-mental pollution, remain in the undecomposed state for longer period e.g. the plastics.

\section{MUNICIPAL WASTE MANAGEMENT}

A study conducted by Operation Research Group (ORG), Baroda on "Delivery and financing of urban services", in 1989, indicated that the management of urban solids wastes in most cities is highly improper and need drastic actions to avoid epidemic/health risks to their citizens. The studies (ORG, 1989; MoEF, 1993) earlier highlighted the major problems in waste management in a few metro cities (Table 9). With continuous population growth in these metropolitan cities, at an average rate of more than $4 \%$ every year, one could calculate the quantum of solid waste generation and thereafter annual increment in their generation. The population for first ten out of 23 metropolitan cities as per 2001 census data is given in Table

Table 9: Urban solid wastes generation, collection and disposal methods in few major cities of India based on 1988 data.

\begin{tabular}{|c|c|c|c|c|c|}
\hline City & Population & Generation & Collection & $\begin{array}{l}\text { Collection } \\
\text { efficiency }\end{array}$ & Method of disposal \\
\hline Mumbai & $8,227,332$ & 3200 & 3100 & 96.9 & $\begin{array}{l}\text { Collected initially at } 4975 \text { temporary points and } \\
\text { then all the solids wastes is transported in } \\
\text { vehicles for disposal at different landfill (sites } \\
\text { in suburbs using unsanitary landfill) method. }\end{array}$ \\
\hline Chennai & $4,276,635$ & 1819 & 1637 & 90.9 & $\begin{array}{l}\text { Collected at temporary collection points and } \\
\text { then transported in vehicles/bullock cart using } \\
\text { semi controlled or crude dumping at twomajor } \\
\text { and four smaller disposal sites. }\end{array}$ \\
\hline Delhi & $5,729,000$ & 2900 & 2500 & 86.0 & $\begin{array}{l}\text { Delhi can boast of having the county's best } \\
\text { sanitary landfill site which takes about } 2400 \\
\text { tonnes of urban wastes every day. About } 100 \\
\text { tonnes of wastes is converted into compost } \\
\text { manure in compostplant (capacity } 150 \text { tonnes) }\end{array}$ \\
\hline Bangalore & $2,913,537$ & 1800 & 1225 & 68.1 & $\begin{array}{l}\text { The majority of the solid wastes is disposed of } \\
\text { using unsanitary landfill methods at different } \\
\text { sites within city limits. A semi mechanized } \\
\text { compost plant with a capacity of } 200 \text { tonnes/ } \\
\text { day is in operation in the outskirts of the city. In } \\
\text { addition a refuse derived fuel plant(RDF) has } \\
\text { alsobecome operational recently. }\end{array}$ \\
\hline Ahmedabad & $2,515,195$ & 1200 & 1080 & 90.0 & $\begin{array}{l}\text { Entire wastes generated in the city is disposed } \\
\text { off by sanitary landfilling. }\end{array}$ \\
\hline
\end{tabular}


10. There is an immediate need to adopt scientific landfill method in all cities. Further keeping in view the fast rate of generation of solid wastes in metropolitan /class I cities, possibilities should be explored not only for additional landfill sites but for all other options where solid wastes could be utilized for beneficial purposes including generation of energy from biomass and other useful products.

Table 10: Population of ten metropolitan cities as per 2001 census

\begin{tabular}{lr}
\hline City & Population \\
\hline Mumbai & $12,596,243$ \\
Kolkata & $11,021,918$ \\
Delhi & $8,419,084$ \\
Chennai & $5,421,985$ \\
Hyderabad & $4,344,437$ \\
Bangalore & $4,130,288$ \\
Ahmedabad & $3,312,216$ \\
Pune & $2,493,987$ \\
Kanpur & $2,029,889$ \\
Lucknow & $1,669,204$ \\
\hline
\end{tabular}

\section{THE PLASTICS WASTES AND MANAGEMENT}

The plastics products viz., carry bags, blood bags, coloured plastic pots are fast becoming popular in both rural and urban India. The packaging and poly vinyl chloride (PVC) pipes industry are growing at $16-18$ per cent per annum. The demand of plastics goods is increasing from house hold use to industrial applications. It is growing approximately at an annual rate of 22 per cent. During 2000-2001, about four million tonnes of plastics or polymer were consumed in India. Table 11 provides the details on the consumption of plastics which may reach to 7.5 million tonnes by 2006-07 (Nanavate, 1997; Annon, 1997). The polymer production capacity is expected to reach 3.5 million tonnes by the end of 2003. Increase in capacities and liberalization of trade of polymer products will lead to increase in per capita consumption of plastics in India. Additional Annual demand is expected to be more than one million tones (Table 12, CSE, 2002).

The major environmental problem associated with plastics wastes is that plastics do not degrade and they persist for longer period posing a risk to health. The annual per capita consumption of plastics in India is two $\mathrm{kg}$ compared to global average of $17.5 \mathrm{~kg}$. The Asian
Table 11: Total plastic consumption in India (in tonnes)

\begin{tabular}{llc}
\hline S. No. & Year & Consumption \\
\hline 1. & 1996 & 61,000 \\
2. & 2000 & $3,00,000$ \\
3. & 2001 & $4,00,000$ \\
5. & 2007 & $7,500,000$ (projected) \\
\hline
\end{tabular}

Table 12: Demand for polymers in India

( Demand of plastics in India ( in kilogramme tones )

\begin{tabular}{llrrr}
\hline $\begin{array}{l}\text { S. } \\
\text { No. }\end{array}$ & $\begin{array}{l}\text { Type of } \\
\text { polymer }\end{array}$ & $1995-96$ & $2001-2002$ & 2006-07 \\
\hline 1. & Polyethlene & 823 & 1,835 & 3,267 \\
2. & Polypropylene & 340 & 885 & 1,790 \\
3. & Poly vinyl chloride & 489 & 867 & 1,287 \\
4. & Poly ethylene terephthalate & 34 & 140 & 289 \\
\hline
\end{tabular}

annual average is $10 \mathrm{~kg}$ per capita. More than one-fourth of the consumption of plastics in India today is that of PVC - a chemical which is being phased out in some countries. The data reveal the following:

1. Nearly $45-60$ per cent of all plastics waste is brought back to use by recycling virgin Plastics based goods.

2. From discarded computer chip boards to polythene bags all go through repeated "down cycling".

3. Polypropylene (PP) and high density polyethylene (HDPE) are two polymers that are recycled the most.

4. Almost 45 per cent of the total plastic consumed in the country gets converted to plastics waste.

5. About 45 per cent of this gets recycled. Thus about 20 per cent of the annual polymer consumption or about 800,000 tonnes of plastics being recycled.

As recycling is done repeatedly the volume of recycled plastic in the market keeps increasing. It, therefore, becomes a large enough chunk for the virgin plastic manufacturers to worry about competition. The manufacturers often mention the recyclers as important agencies managing the plastics wastes. The recyclers in India also import a lot of plastics waste to regurgitate back into the markets. Import of plastics waste under licence is allowed, however a substantial amount do come to the country without licence. It was highlighted by the highpowdered committee on the management of hazardous wastes set up by the Supreme Court of India in 1997. It reported that in the year 1994- 
95, 24240 tonnes of plastics scrap was imported illegally (CSE, 2002).

\section{ENVIRONMENTAL IMPACT}

Most common method of disposing of wastes is to dump them in low-lying areas on the outskirts of towns which is very haphazard and unscientific. This has serious environmental impacts like water pollution, methane emissions, and soil degradation (Rao and Shantaram, 1996). The average density of Indian municipal waste at the point of collection varies from 400 to 600 $\mathrm{kg}$ per cubic metre. At the landfill site, however, the density is much higher because of compaction and putrefaction. Compactors were introduced in India in the late 1970 s by a few large corporations to make the transportation of waste more efficient. The waste is compacted with a hydraulic press fitted within a truck or at the landfill site. If the waste is not compacted, it putrefies with time. The density of dumped refuse can increase two folds in about six months due to putrefaction and self-compaction of biodegradable organic matter. The average density of waste at the landfill site can be assumed to be approximately 1 tonne per cubic metre (Sivapullaiah, 1977). The average depth of a landfill site in India is 4 metres. A survey of literature reveals that only limited information is available on soil contamination. However, it has been observed that soil can be contaminated with soluble salts and metals from solid wastes which may cause dispersion of soil particles, thus adversely affecting soil structure. On the other hand, the compostable part of municipal solid waste if separated can be a good source of manure. As traditional disposal sites do not have an impermeable lining, contamination to surface water and groundwater is by far the most serious environmental impact. Surface run-off and leachate from dump-sites can easily contaminate natural sources of water. The composition of leachate depends on many factors such as the composition of waste, elapsed time, temperature, moisture, available oxygen, and management practices. The typical constituents of leachate from MSW are given in Table 13 (Datta, 1997).

Leachate characteristics at disposal sites reveal that values of TDS (total dissolved solids), chloride, TOC (total organic carbon), and COD (chemical oxygen demand) are always more for pit leachates than for extractable pollutants from degradable solid waste. However, there is a lot of variation in toxic heavy metals in pit leachate and in extractable pollutants, indicating that degraded solid waste generates very strong leachate containing high organic and inorganic pollutants and may contaminate the water bodies. Once contaminated, the cost of treating groundwater and surface water is prohibitive. And the cost, in terms of ill health and the subsequent loss in productivity are even higher. Although rag pickers collect major part of the recyclable wastes and sell it to middlemen, only about $70 \%$ of MSW is collected. A part of the waste generally goes into sewers but most of it is burnt in the open, thereby polluting the air.

The other source of air pollution is due to decomposition of the biodegradable component

Table 13: Characteristics of landfill leachates

\begin{tabular}{|c|c|c|c|}
\hline Parameter & $\begin{array}{l}\text { Concentration } \\
(\mathrm{mg} / \text { /litre })\end{array}$ & $\begin{array}{l}\text { Parameter } \\
\text { (mg/litre) }\end{array}$ & Concentration \\
\hline $\mathrm{pH}$ & $3.7-8.9$ & Arsenic & $0-70.2$ \\
\hline Turbidity & $30-500 \mathrm{JTU}$ & Mercury & $0-3.0$ \\
\hline Conductivity & $480-72500 \mathrm{umho} / \mathrm{cm}$ & Cyanide & $0-6.0$ \\
\hline Total suspended solids & $2-140900$ & C. O. D. & $50-99000$ \\
\hline Total dissolved solids & $725-55000$ & Total organic carbon & $0-45000$ \\
\hline Chlorides & $2-11375$ & Acetone & $140-11000$ \\
\hline Sulphates & $0-1850$ & Benzene & $2-410$ \\
\hline Hardness & $300-225000$ & Toluene & $2-1600$ \\
\hline Alkalinity & $0-20350$ & Chloroform & $2-1300$ \\
\hline TKN (total kjeldahl nitrogen) & $2-3320$ & 1,2 dichloroethane & $0-11000$ \\
\hline Sodium & $2-6010$ & Methyl ethyl ketone & $110-28000$ \\
\hline Potassium & $0-3200$ & Napthalene & $4-19$ \\
\hline Calcium & $3-3000$ & Phenol & $10-28000$ \\
\hline Magnesium & $4-1500$ & Vinyl chloride & $0-100$ \\
\hline Lead & $0-14.2$ & B. O. D & $0-19500$ \\
\hline Copper & $\begin{array}{ll}0 & -9.0\end{array}$ & & \\
\hline
\end{tabular}


in landfills. Waste in landfills is initially degraded aerobically, using up oxygen and converting the organic matter to carbon dioxide. After sometime further degradation is anaerobic, during which methanogenic bacteria generate methane. Landfill gas typically contains $40 \%$ to $60 \%$ methane by volume and carbon dioxide. Methane can be an environmental hazard by migrating from landfills either laterally or upward into the atmosphere. At low concentration, it can damage vegetation and cause unpleasant odours but at higher concentrations it forms explosive mixtures.

The role of methane in global atmospheric changes has received increasing attention recently. Methane from landfills contributes significantly to annual global emissions of methane. Although actual emission is estimated with a great deal of uncertainty, yet methane has a global warming potential up to 63 times to that of carbon dioxide (depending on the time horizon) and accounts for about $15 \%$ of the global warming due to anthropogenic emissions (Brown, 1994). Municipal waste is rich in organic matter and moisture and anaerobic conditions quickly develop in the lower layers of landfills. Since this methane is allowed to escape, it contributes significantly to the warming of the atmosphere. The estimated potential of methane emissions from landfills during the past 50 years, calculated by using the method of Bingemer and Crutzen (1987) is in the range of 0.87 (1994) to 7.10 (1997). Buildings constructed on completed landfills inherit the potential problems of methane, corrosion, weak foundation, and the tendency of landfills to sink. Entire residential complexes built on such sites may virtually stand on a methane gas bomb. There are instances of landfill sites being converted into recreational parks which, instead of improving people's health, can damage it irreparably.

\section{ECONOMIC IMPACTS}

A large proportion of recyclable components, i.e., paper, plastics, metal, etc. is collected by rag pickers from the garbage bins, from roadside, or in streets, market places, etc. in metropolitan cities, thus supplying raw material to the flourishing recycling units. About 0.75 million tones of plastics wastes are recycled every year in India. In such metro cities as Delhi and
Mumbai, this business is very lucrative and can fetch anything between Rs 3 to Rs 15 per kg at each stage of the transfer. The plastics recycling industry in India is valued at 25 billion rupees at the pregranulation stage and 39 billion rupees at the post-granulation stage. In smaller cities and towns, about $14 \%-20 \%$ of the total garbage consists of recyclable items (TERI, 1998). This excludes the plastics and paper retained in the households to be sold. Polythene bags made from pure petroleum granules of 50\% LDPE (Lowdensity polyethylene) and 50\% HDPE (Highdensity polyethylene) sell for about 56 rupees a tonne, those made from recycled granules of LDPE and HDPE in the same proportions cost only 35 rupees a tonne (Venkateswaran, 1995). Taking the urban population of India in 1991 as 217.18 million, the total garbage generated in that year works about to 37 million tones. The share of plastics in this figure would amount to 1.3 million tones, representing a monetary loss of 29 million rupees in 1991 alone.

The landfill gas can be used as substitute of fossil fuels, generating additional revenue and reducing pollution. Lately, conversion of landfill gas into powder has become a lucrative business in the developed world. Composting the organic portion of municipal solid waste can produce 0.6 million tones of organic fertilizer every year, which could partially offset the degradation of land and pollution due to indiscriminate application of chemical fertilizers. Due to foul odours emanating from landfills and explosion hazards due to emissions of methane, a 1- to 2$\mathrm{km}$-wide strip around the site is unsuitable either for habitation or for plant life. As a result, the land is left unused, despite acute scarcity of land in cities and the soaring land prices.

\section{IMPACTS ON HUMAN HEALTH}

The poor waste management is associated with increased health problems ranging from epidemics of vector-borne or food/borne diseases to the adverse effects due to contamination of groundwater. The effects of such health hazards are difficult to quantify because of limited epidemiological studies:

The health hazards can be categorized as follows.

- Direct contact with waste in the case of rag pickers who separate recyclable material from the waste. 
- Direct contact with waste in the case of workers involved in waste disposal.

- Indirect effects because of contamination of soil, air, and water as a result of poor management of landfill sites.

The municipal workers handle wastes mostly without protective devices like gloves or waterproof boots. The workers can be infected at all stages, from collecting the waste at source to handling it at landfill sites. The pathogens can enter either through skin and mucous membranes or along with inhaled air. As can be seen in Table 14, the incidence of respiratory diseases, skin diseases, etc. is much greater amongst those who handle wastes than amongst the general population. Flies are the most visible indicator of unsanitary conditions. If wastes are not covered, the eggs of flies not buried deep inside the wastes easily survive. It is estimated that in exposed garbage, the population of flies can reach as much as 2.33 million in a week for every cubic metre of garbage. If the garbage contains night-soil, pathogens like enteropathogens, Shigella, Salmonella, and Entamoeba adhere to the feet of these flies. The flies then alight on food kept in the open and thus transmit the pathogens to those who eat the contaminated food. Apart from such health hazards, swarms of flies near garbage dumps are a nuisance. Waste picking is considered to be at the bottom of the social and economic hierarchy of activities within the unorganized sector and requires neither education nor specific skills. Therefore, it is generally children, often less than 10 years old, and women, who earn a living as rag pickers. At a rough estimate, about 35000 children work as rag pickers in Bangalore and

Table 14: Incidence of diseases in refuse workers and in general population, based on NEERI (1971).

\begin{tabular}{lcc}
\hline Disease & $\begin{array}{c}\text { \%of incidence } \\
\text { among 50 } \\
\text { refuse workers }\end{array}$ & $\begin{array}{c}\text { \% incidence } \\
\text { in a control } \\
\text { group of } 70\end{array}$ \\
\hline Anaemia & 24 & 16 \\
Gastrointestinal & 38 & 26 \\
Respiratory Diseases & 62 & 24 \\
Skin Diseases & 32 & 14 \\
Jaundice & 42 & 6 \\
Trachoma & 23 & - \\
Eosinophilia & & 9 \\
Below 5\% & 28 & 12 \\
6\%-10\% & 20 & 6 \\
11\%-20\% & 44 & \\
\hline
\end{tabular}

about 80000 in Delhi. Studies conducted in Delhi (Sanon, 1986) and Bangalore (National Institute of Public Cooperation and Child Development) found that the majority of child rag pickers are between 8 and 15 years old and that a large proportion of them start work when they are between 5 and 8 years old. About $75 \%$ to $80 \%$ of them are boys. As these children begin working so early in life, they never have the opportunity to study or to acquire skill for better job.

It is seldom realized that rag pickers serve a useful function. Assuming that, on an average, a rag picker collects about $10 \mathrm{~kg}$ waste each day and that there are 80000 of them in Delhi, the total quantum of waste collected by the pickers is 800 tonnes daily, which is approximately $18 \%$ of the total waste generated every day. The Municipal Corporation of Delhi spent approximately 1.2 billion rupees (1995/96) to mannage 1.98 million tones of garbage generated during the year. Thus, the rag pickers saved the municipal authorities more than 182 million rupees which otherwise would have been spent on handling 0.29 million tones of additional garbage (TERI, 1998).

\section{ENVIRONMENTAL MANAGEMENT OPTIONS}

\section{Existing Legislation}

Management of municipal solid waste is essentially the duty and responsibility of municipal corporations in India and the constitution and powers of municipal corporations are a subject included in the 'State List' in the Seventh Schedule of the Indian constitution. Each state has its own Municipal Acts, by and large, framed on similar lines. The municipal corporations have to deal with health and sanitation, primary education, construction and maintenance of roads and bridges, healthcare, registration of births and deaths, inspection and licensing of food, and so on. Management of solid waste is low on the priority list of authorities and seldom funded adequately. Most of the Municipal Acts have all the necessary legal provisions to (1) take action against the civic officials if they fail to provide a clean and safe environment to the general public and (2) penalize those who spoil the environment. In the absence of proper enforcement, municipal waste 
is disposed of with little regard to the environment, resulting in serious environmental problems. The 'public-interest litigations' are being filed in various High Courts / Supreme Court to legally compel the corporations to provide effective civic amenities. The Indian Constitution has specific provisions on environmental protection which deal with safeguarding and protecting the environment, including air, water, and land. The $73^{\text {rd }}$ amendment of 1992 on panchayats, under $11^{\text {th }}$ schedule, eight entries relating to protection and conservation of environment were made in the constitution. The sixth entry of the $12^{\text {th }}$ schedule (Article 243 [W], 74 $4^{\text {th }}$ Amendment) unambiguously empowers the local bodies to effectively deal with the issue of public health, sanitation, conservancy, and solid waste management.

Under the Environment (Protection) Act, 1986, the Municipal Wastes (Management and Handling) Rules, 2000, have been notified where the provisions for maintaining the environmental quality have been explicitly mentioned. Important provisions are described below:

\section{Responsibility of the Municipal Authority:}

(1) Every municipal authority shall, within the territorial area of the municipality, be responsible for the implementation of the provisions of these rules, and for any infrastructure development for collection, storage, segregation, transportation, processing and disposal of municipal solids wastes.

(2) The municipal authority or an operator of a facility shall make an application in the prescribed form, for grant of authorization for setting up waste processing and disposal facility including landfills from the State Board or the Committee in order to comply with the implementation programme laid down in the notification.

(3) The municipal authority shall comply with these rules as per the implementation schedule laid down.

(4) The municipal authority shall furnish its annual report in the standard form to the Secretary-in-charge of the Department of Urban Development of the concerned State or as the case may be of the Union territory, in case of a metropolitan city, or to the District Magistrate or the Deputy Commissioner concerned in case of all other towns and cities, with a copy to the State Pollution Control Board or the Committee on or before the $30^{\text {th }}$ day of June every year.

Responsibility of the State Government and the Union territory Administrations:

(1) The Secretary-in-charge of the Department of Urban Development of the concerned State or the Union territory, as the case may be, shall have the overall responsibility for the enforcement of the provisions of these rules in the metropolitan cities.

(2) The District Magistrate or the Deputy Commissioner of the concerned district shall have the overall responsibility for the enforcement of the provisions of these rules within the territorial limits of their jurisdiction. Responsibility of the Central Pollution Control Board and the State Pollution Control Board or the Committees:

(1) The State Pollution Control Board or the Committee shall monitor the compliance of the standards regarding ground water, ambient air, leachate quality and the compost quality including incineration standards as specified in the notification.

(2) The State Pollution Control Board or the Committee, after the receipt of application from the municipal authority or the operator of a facility, as specified in the notification, for grant of authorization for setting up waste processing and disposal facility including landfills, shall examine the proposal taking into consideration the views of other agencies like the State Urban Development Department, the Town and Country Planning Department, Air Port or Air Base Authority, the Ground Water Board or any such other agency prior to issuing the authorization.

(3) The State Pollution Control Board or the Committee shall issue the authorization (in the specified form) to the municipal authority or an operator of a facility within forty-five days stipulating compliance criteria and standards as specified in the notification including such other conditions, as may be necessary.

(4) The authorization shall be valid for a given period and after the validity is over, a fresh authorization shall be required.

(5) The Central Pollution Control Board shall co-ordinate with the State Pollution Control Boards and the Committees with particular reference to implementation and review of standards and guidelines and compilation of monitoring data. 


\section{Best Practices}

As far as the management aspects of solid wastes are concerned, the following possibilities are of significance to us:

1. Reduction in raw material use.

2. Reduction in generation solid waste quantities.

3. Reuse of solid waste materials.

4. Recovery of materials/metals.

5. Generation of energy/biogas.

6. Conversion into useful products such as fertilizers, fuel pellets etc.

7. Reduction in quantity of solid wastes through incineration/pyrolysis

8. Disposal of solid wastes (land filling).

Reduction in Raw Material Use: The generation of solid wastes is directly related to the quantity or consumption of raw material, as conversion efficiency of any process can't be 100 percent. Hence, reduction in usage of raw material either through technological intervention or imposing restriction/guidelines is desirable to reduce the load of solid wastes.

Reduction in Generation of Solid Wastes Quantities: There is a strong need to reduce the generation of solid wastes in any system, through inbuilt mechanisms/processes or adopting technology of high conversion efficiency or even by producing quality product. The quality product compared to inferior grade products would reduce the generation of solid wastes effectively. For example, production of quality automobile tyres, with more life span would reduce the quantum of solid wastes contributed by them, when discarded.

Recovery of Materials/Metals: Recovery of useful materials/metals from solid waste is an important consideration in management. The recovery on techno-economical basis, of particularly materials/metal, will cut down the demand on usual production, thereby serving dual purpose in reduction in overall quantity of solid wastes. The materials /metals recovered from solids waste in United States (year 1975) are given in Table 15 which indicates recovery is certainly a better option.

\section{THE RECYCLING SCENARIO}

Recycling Plastics Wastes: According to a primary survey done by TERI in 1996, plastics waste accounted for $4 \%-9 \%$ of the waste across
Table 15: Recovery of materials from the solid wastes (Peavy et al., 1988).

\begin{tabular}{lccc}
\hline \multirow{2}{*}{ Material category } & \multicolumn{3}{c}{ Material recycled } \\
\cline { 2 - 4 } & Gross & Quantity & Percent \\
\hline Paper & 44.1 & 6.8 & 15.4 \\
Brass & 13.7 & 0.4 & 2.9 \\
Metals & 12.7 & 0.6 & 4.7 \\
Ferrous & $(11.3)$ & $(0.5)$ & $(4.4)$ \\
Aluminium & $(1.0)$ & $(0.1)$ & $(10.0)$ \\
Other nonferrous & $(0.4)$ & $(0.0)$ & $(0.0)$ \\
Plastics & 4.4 & 0.0 & 0.0 \\
Rubber & 2.8 & 0.2 & 7.1 \\
Leather & 0.7 & 0.0 & 0.0 \\
Cables & 2.1 & 0.0 & 0.0 \\
Wood & 4.8 & 0.0 & 0.0 \\
Others & 0.1 & 0.0 & 0.0 \\
Total non-food & 85.4 & 8.0 & 9.3 \\
product waste & & & \\
Food waste & 22.8 & 0.0 & 0.0 \\
Non-food waste & 26.0 & 0.0 & 0.0 \\
Miscellaneous & 1.9 & 0.0 & 0.0 \\
$\quad$ inorganic wastes & & & \\
\hline Total & & 8.0 & 5.9 \\
\hline
\end{tabular}

different income groups of the Indian Society. In 1971 , it was only $0.7 \%$. Nearly all plastic wastes are sold to kabariwallahs, who form the first link in the chain of recycling plastics. Smallscale recycling units getting the plastics wastes from the kabariwallahs create adverse environmental impacts due to outdated technology, poor quality of raw material, and the absence of government support. They, however, help save the scarce and valuable virgin raw material and the large stretches of land needed for the disposal of wastes and its detrimental effect on the environment and offer employment also. In plastics industry, the raw material accounts for about $70 \%$ of the total production cost. Therefore, plastic recycling can save large quantities of petro-based virgin material. Unfortunately, plastics waste recycling continues to be a disorganized and technically backward sector.

Recycling Waste Paper: The recycling of paper from the municipal solid wastes is not impressive. Some of the paper mills make use of the waste paper as raw material for manufacturing of paper again. However, many paper mills that use waste paper prefer to use imported waste paper because of quality deterioration of local material due to unorganized collection. Each tonne of imported waste paper can produce as much as 0.9 tonne of recycled paper, which is considerably higher than the figure of 0.4 tonne 
for agro-pulp and 0.5 tonne for wood pulp. Also, waste-paper-based production is far less polluting. In 1990/91, India utilized about 29\% of its waste paper (Sharma et al., 1996), as compared to the global average of $36 \%$. The recovery rate was $14 \%$ compared to global recovery rate, which was as high as $37 \%$. About 6\%-10\% of the household waste consists of paper reaching landfill because it is not sorted and separated. However, a small percentage which has not been soiled by other wastes is recovered by the vast network of rag pickers in large towns and cities and recycled. The major metropolitan cities in India have also not been able to augment the recovery, sorting and bailing of waste paper. The recovery and recycling of waste paper need more institutional or governmental support. In the absence of financial incentives and the latest technology, paper-recycling industry remains an undeveloped industry. There is enough scope to develop small scale industries in this sector having good employment generation potential.

Recycling Glass: Glass is another component of municipal solid waste that is normally recycled. It is usually picked up by rag pickers and reaches the glass industry through dealers. Waste glass is generally used in producing the three types of glass products viz. (i) containers and hollow wares (ii) Sheet glass and (iii) flat glass. Although, the authors could not collect much of the information on quality of generation and recycling, it is expected that glass recycling shall be convincingly at acceptable limit due to easy collection and recycling.

Reuse of Solid Waste Materials : Reuse (recycling) need to be stressed in situation, where a product has utility in more than one application. Oil/beverage containers could be used to store household items. Plastic/paper bags could be used for collection of household wastes. Soft drink or beer container / bottle could be recycled to the maximum extent possible. Although these measures may sound minor at individual level, but being the first point of generation of solid wastes, the overall impact of these measures, if implemented effectively, shall be quite significant in reducing the load of solid wastes, particularly the municipal wastes.

Generation of Energy/Biogas: The biodegradable/organic solid wastes could be utilized for generation of energy depending upon their calorific value (energy content) and other relevant parameters. The solid wastes rich in organic matter could also be used for generation of biogas by anaerobic digestion. Energy may also be recovered through incineration of solid wastes. Anaerobic digestion is a process of decomposition of organic wastes in the absence of oxygen. The organic wastes could be hydrolysed, liquefied and gasified. The gases can be used for fuel and lighting and the mineralized residue can be used as rich manure. There will be appreciable saving in recurring costs because of utilization of this biogas as manure and electricity.

Conversion into Useful Products (Fertilizers and Pellets): Solid wastes rich in organic wastes could also be converted into organic fertilizer/ manure through composting or by using vermiculture biotechnology. High vegetativeputresible content in wastes are ideally suitable for conversion into organic fertilizer rich in nitrogen, phosphate and potash. However, in recent years, the vermiculture biotechnology particularly for converting solid wastes into organic rich manure, has gained momentum as low investment and low price of compost are important propositions of this conversion method. Biotechnology involves efficient utilization of biosystems for economic and effective processing of materials to produce value added products. "Vermiculture" is an aspect of biotechnology which involves the use of earthworm as versatile natural bioreactor for effective recycling of non-toxic organic solid wastes/ biodegradable wastes (kitchen waste including all vegetable and non-vegetable materials, paper, etc.). This technology now being indigenized is more entrepreneur friendly and economical. The only pre-requisite of this process is to separate non-biodegradable materials like plastics, broken glass, metals etc. by keeping a separate container for them in the house or segregating at the dumping site. The advantages of this technique are (i) the sites don't stink, (ii) production of good quality manure, (iii) low capital and operational cost and (iv) easiness to scale up. It is an ideal low solid waste-processing scheme with little capital and energy consumption. A valuable by product, the vermin-casting, rich manure is excellent for use in agriculture and horticulture. Organic solid wastes, depending upon their carbon content, can be used to make cost efficient fuel pellets through the process of pelletization as small cubes having calorific value quite close to coal. Therefore, these pellets are good 
substitute for coal, wood and petroleum products for both domestic and industrial use. An indigenous technology has already been developed by Department of Science and Technology, Govt. of India.

\section{THE TECHNOLOGY}

\section{Incineration/Pyrolysis}

Landfill is the most common method for disposal of wastes in most of the countries (Table 16 ).Each options mentioned above need to be worked out carefully to see whether some waste materials/metals are useful and can be recovered or solid wastes can be used for beneficial purpose (energy, biomass, fertilizer and fuel pellets,etc.). In such process a part of solid wastes could easily be utilized for beneficial use, the remaining may be disposed off, for which the most commonly used method is land filling. As landfill is associated with continuous and long term operation, it is necessary to plan for effective solid waste management to achieve maximum reduction of wastes for disposal and landfill. The commonly used process to reduce the quantum of solid wastes is incineration/pyrolysis. Incineration refers to controlled burning of wastes at high temperature $\left(500-1200{ }^{\circ} \mathrm{C}\right)$ in a furnace especially designed for this purpose and the products of incineration are ashes and gases. Pyrolysis refers to destructive distillation at high temperature in an oxygen free atmosphere. Hydrocarbon, such as cellulose, plastic and rubber, which are long chain compounds are main bulk of the solid wastes. On exposure to high temperature, these are broken down into gases (like $\mathrm{CO}_{2} \mathrm{CO}, \mathrm{H}_{2}, \mathrm{C}_{2} \mathrm{H}_{4}, \mathrm{CH}_{4}$ ) and liquids (like tar, light oil, liquid and water soluble distillate) and solid tar. In addition, we can also obtain energy waste heat to operate turbine generators/ heat recovery systems.

\section{Operation of Incinerators}

Incineration systems can be generalized to

Table 16: Status of municipal solid waste management in several countries

\begin{tabular}{|c|c|c|c|c|}
\hline \multirow[t]{2}{*}{ Country } & \multicolumn{3}{|c|}{ Current disposal (\%) } & \multirow[t]{2}{*}{ Comment } \\
\hline & Recycling & Landfill & $\begin{array}{l}\text { Waste-to- } \\
\text { energy }\end{array}$ & \\
\hline Germany & 18 & 46 & 36 & $\begin{array}{l}\text { Restricting land-filling to wastes which have less than } 3 \% \text { carbon } \\
\text { content by } 2005 \text {. New waste-to-energy capacity to achieve this } \\
\text { objective. }\end{array}$ \\
\hline Austria & 24 & 65 & 11 & Aims by 2004 to ban landfill to more than $5 \%$ organics. \\
\hline Switzerland & 29 & 12 & 59 & Banning of landfilling of combustible waste. \\
\hline France & 13 & 45 & 42 & $\begin{array}{l}\text { Banning landfilling of combustible by } 2002 \text {. Landfill levy of } \\
20 \mathrm{FFr} / \mathrm{t} \text { plus other air pollution taxes. Looking to increase EfW*. }\end{array}$ \\
\hline Sweden & 19 & 34 & 47 & $\begin{array}{l}\text { Aims to further decrease reliance on landfill by increasing } \\
\text { recycling and } \mathrm{EfW}^{*} \text { rates. }\end{array}$ \\
\hline Denmark & 23 & 29 & 48 & $\begin{array}{l}\text { Banning of landfilling of combustible waste by } 1997 \text {. Plans to } \\
\text { increase recycling and EfW*. }\end{array}$ \\
\hline Netherlands & 20 & 45 & 35 & $\begin{array}{l}\text { Landfilling of combustibles, cardboard and paper banned. Direct } \\
\text { landfilling of other MSW components banned by } 2000 \text {. }\end{array}$ \\
\hline Japan & $5^{2}$ & $23^{3}$ & 72 & On target to achieve $75 \%$ waste-to-energy by 2000 . \\
\hline USA & 22 & 62 & 16 & $\begin{array}{l}\text { Projections to increase waste-to-energy to } 25 \% \text { by } 2005 \text {. (current } \\
\text { figure includes } 1 \% \text { incineration) }\end{array}$ \\
\hline Norway & 11 & 67 & 22 & \\
\hline Belgium & 3 & 43 & 54 & $\begin{array}{l}\text { New waste-to-energy capacity under construction. Soon to ban } \\
\text { direct landfilling of combustible MSW. }\end{array}$ \\
\hline UK & 3 & 90 & 7 & $\begin{array}{l}\text { Recycling target of } 25 \% \text { by } 2000 \text {. Plan to introduce landfill tax } \\
\text { in } 1996 .\end{array}$ \\
\hline Canada & 21 & 74 & 5 & \\
\hline Finland & 15 & 83 & 2 & $\begin{array}{l}\text { Pursuing policies to encourage combustion of MSW with other } \\
\text { fuels. }\end{array}$ \\
\hline Average & 16 & 51 & 33 & \\
\hline
\end{tabular}

EfW ( Energy from Waste )

Source: Municipal Solid Waste Mass Burn: January, 1997)and ETSU, UK Department of Trade and Industry. 
include the following four basic operations:

1. First the waste prepared, stored and transported to the incinerator in a physical form conducive to the combustion process.

2. The incinerator furnace is designed on the basis of the physico-chemical properties of the wastes being handled. Under controlled conditions of combustion, the toxic organics are thermally oxidized to form flue gases.

3. These gases are cooled directly through quenching or dilution devices or indirectly by employing waste heat recovery systems and special types of boiler.

4. The final step removes the pollutants in the flue gases by subjecting them to ventury scrubbing, mass transfer operations, filtrations, etc to reduce the emission to acceptable levels before letting them out into the atmosphere.

\section{Technological Advances in Incinerators}

Fluidized Bed Incinerators (FBI) is a simple and less expensive system superior to traditional rotary kiln incinerators. The costs of FBI's are generally one tenth the cost of rotary kiln incinerators. Even much cheaper alternative to FBI, are catalytic incinerators which are used for toxic fume destruction. Mobile incinerators for individual small industries are also effective to incinerate quantity of solid wastes (toxic). Efficiency of incinerators, particularly at shut down, starts up and operational phase is determined by percentage conversion of principal organic hazardous constituents (POHC) as:

$\begin{aligned} & \text { Destruction } \\ & \text { and Removal }= \\ & \text { efficiency (DRE) }\end{aligned}$
$\begin{gathered}\text { of POHC } \\ \text { Mass feed rate of POHC }\end{gathered}$

This efficiency should be $99.9 \%$.

\section{Disposal of Solid Wastes (Land Filling)}

The main objective in management of solid waste should be to choose options which are techno-economically feasible and reduce the matter to "bare minimum" which required to be disposed off at land fill site. All such options referred earlier for management of solid wastes are, meant for reducing their quantity. For such options incineration is significant in minimization of voluminous wastes. The remainder of solid wastes after all options for reducing their quantity effectively still pose problems in their disposal. Such municipal and industrial wastes could be difficult to handle because of their voluminous quantity, whereas hazardous wastes may pose problems due to their toxicity. These wastes should be disposed in scientifically designed secured sites.

The main problem faced in landfill disposal is availability of land itself, pollution of water and soil. Both these problems to some extent could be minimized if the landfill area is scientifically designed, properly compacted and clay lined before dumping of wastes. The hazardous wastes could be treated properly through physical/ chemical/biological methods before being dumped in landfill areas or disposed off in containers in underground/ocean. For the disposal of different types of solid waste, two important considerations are (i) site selection and (ii) movement and control of gases and leachates in landfill area.

\section{Site Selection}

The factor to be considered in evaluating the potential impact of a solid waste disposal site is summarized in Table 17. Engineering design, cost and environmental impact assessment are generally the deciding factors in site selection. The parameters in selection of these disposal sites are to (i) minimize health risks, (ii) minimize adverse environmental impacts, (iii) minimize cost and (iv) maximize public acceptability. Certain specified areas are to be avoided for disposal of solid wastes and more particularly for hazardous wastes so as to minimize environmental impacts including contamination of surface and ground water. These are:

- Eco-sensitive areas

- Existing zones of urban and rural development

- Prime agriculture land

- Fresh water wetlands

- Visual corridors of scenic rivers

- Riverine and dam related areas

Movement and Control of Gases and Leachates in Landfill Areas: The solid wastes into landfill area undergo a series of changes in bio-chemical composition due to biological decay of organic materials either aerobically or anaerobically and chemical oxidation. As a result gaseous and liquids (leachates) emissions occur. 


\begin{tabular}{ll}
$\begin{array}{l}\text { Table 17: Factors to be considered in evaluating potential } \\
\text { impact of landfill sites (Peavy et al., 1988) }\end{array}$ \\
\hline Factor & \multicolumn{1}{c}{ Remarks } \\
\hline Available land area & $\begin{array}{l}\text { Site should have a useful life } \\
\text { greater than 1 year } \\
\text { (minimum value) }\end{array}$ \\
Haul distance & $\begin{array}{l}\text { Will have significant } \\
\text { impact on operating costs. } \\
\text { Cover material must be } \\
\text { available at or near the site. }\end{array}$ \\
Soil conditions and topography & $\begin{array}{l}\text { Impact drainage } \\
\text { requirements } \\
\text { Probably most important } \\
\text { factors in establishment of } \\
\text { landfill site, especially with } \\
\text { respect to site } \\
\text { preparation. } \\
\text { Noise, odour, dust, vector, } \\
\text { and aesthetic factors control } \\
\text { requirements. } \\
\text { Affects long-term } \\
\text { management for site. }\end{array}$ \\
Conditions & $\begin{array}{l}\text { mydrology } \\
\text { Leologic and hydrologic }\end{array}$ \\
conditions & Ultimate use of site
\end{tabular}

Methane and carbon dioxide gases are produced from anaerobic decomposition of the organic solid waste compounds. Methane, being lighter than air, can easily escape out to atmosphere by providing proper venting system. However carbon dioxide being 1.5 times as dense as air tends to move towards the bottom of the landfill. The downward movement of gases can be controlled by installing perforated pipes at the bottom (gravel layer) of the landfill. Liquids released due to bio-chemical reactions (generally referred as leachates) and other liquids from external source (surface drainage, rainfall, ground water and water from underground springs) can easily percolate through solid wastes in landfill area and can pollute the underground water which becomes a serious concern in case of hazardous wastes. Thus it becomes necessary to collect and treat the leachates. Collection and treatment of leachates may not be economically feasible for non-toxic municipal and industrial wastes. For such wastes clay bottom lining could be used for reducing or eliminating the percolation of leachates. Further the chemical and biological constituents of the leachates also get removed by filtering and absorptive action of material of the strata. Sanitary land-fill should be used for dumping of these wastes. In case of hazardous wastes, we have to collect and treat the leachates from scientifically well designed site with lining area and collection system.

\section{Sanitary Landfill}

Sanitary landfill is a method of disposing the refuse on land without nuisance or hazards to public health or safety. The precautions to confine the refuse to smallest practical area, to reduce it to the smallest practical volume and to cover it with a layer of earth at such intervals may be necessary. The man-made surface derelict land/mineral excavation voids and after improving natural contours like raising the level of low-lying land could be used and after reclamation these lands could be used for cultivation or industrial development.

Design of Landfill Areas for Hazardous

Wastes: The landfill area for safe disposal of hazardous wastes should have two perfectly designed systems: the impervious linear system and leachate management system. It is necessary that liner system should be of materials that have appropriate chemical properties and sufficient strength and thickness to prevent any leakage/ seepage due to accident/failure. The leachate system is designed to collect and remove the leachate generated from landfill. It should not get collapsed or degenerated/rested due to interaction of hazardous wastes.

\section{Municipal Solid Waste Mass Burn}

The publication of IEA Bioenergy Agreement Task XIV ETSU, UK (Annon,.1995) appeared in Municipal Solid waste Mass Burn issue of January, 1997 (Greenhouse Gas Technology Exchange) has been used in this section to detail out the technology and other parameters. Municipal solid waste combustion (MSWC) as process of treatment of municipal waste help minimizing the adverse environmental impacts associated with raw waste land filling, saving transportation costs and landfill requirements by reducing the bulk volume and weight. Combustion, a source of renewable energy, does not significantly affect the buildup of green house gases in the atmosphere. MSWC is the most environmentally sound waste treatment technology and forms an integral part of the waste management infrastructure. It operates with of "mass-burn" technology (MSWMB, 1997). A single large furnace / roller grate system / rotary kiln systems or other combustion (fluidized beds) can be used as mass burn technology to achieve complete combustion by 
efficient mixing of waste and combustion air and to minimize the amount of combustible residue ash, ensuring sanitary treatment and destruction of organic contaminants. An overhead crane removes the oversized items, mixes and evenly distributes combustible materials before feeding to charging hopper and grate (ANNON,1995). The grate agitates and transports the waste to the combustion chamber and the air supplied from under the grate ensures complete combustion and reduces oxides of nitrogen (NOx). Non burnt material and ash are discharged from the end of the grate into a water quench tank from where they are removed for use in construction or other civil technical applications or disposed of in a landfill. The boilers can be used to recover the energy from the hot flue gases for generating electricity. The steam can be used for heating and/ or power combinations. A modern MSWC mass burn system can reduce one tonne of waste to about $291 \mathrm{Kg}$ of bottom ash and give rise to about $45 \mathrm{~kg}$ of fly ash and the flue gas cleaning residue for disposal. The volume of the original waste is reduced by $90 \%$. The gross energy output would be approximately $670 \mathrm{KWh}$ per tonne of MSW and net energy output $6000 \mathrm{KWh} / \mathrm{t} \mathrm{MSW}$. With an operating availability of $85 \%(7,446$ hours per year) the power output for export would be 32 MW enough for over 17,000 homes (Annon, 1995).

Management of Pollutants: Multi-stage pollution control systems, acid gas scrubbers and high efficiency electrostatic precipitators are highly efficient to reduce impact and to remove acid gas, dust, fine particulate from flue gases before exhausting to the atmosphere via a stack. Activated carbon is used for additional mercury and dioxin control. $\mathrm{CO}, \mathrm{NO}_{\mathrm{x}}$ hydrocarbons, and other volatile organic compound emissions can be minimized by optimizing the design and combustion process. Multi-stage scrubbing and filtrations systems are very effective in controlling the dust, acid gases $\left(\mathrm{HCl}, \mathrm{SO}_{2} \mathrm{HF}, \mathrm{NO}_{\mathrm{x}}\right.$ and heavy metals and to mitigate dioxin emissions. Liquids used for gas cleaning are treated and recycled back in the plant or evaporated out. $100 \%$ recycling of treated effluent can be achieved in such plants with zero discharge. The solid wastes like bottom ashes, fly ash and flue gas cleaning residues can be used as a road construction material or disposed in a suitable disposal site, either separately or combined with the grate residue or further treatment should be done. Wet solids and residues from the water treatment plant may be subjected to similar disposal. Activated carbon used to control dioxin and heavy metal emissions, may be sent for incinerating in a separate combustion process. The dioxins, a family of 210 related cyclic chlorine-hydrocarbon chemicals produced in combustion in trace quantities are highly toxic. These can be controlled by the use of dry scrubber / fabric filter systems and carbon injection and activated carbon filters. Good conduction practice and proper temperature control in the flue gases also help reducing dioxin emissions.

Energy Recovery: The energy obtained at high temperature combustion of waste can be utilized for electricity generation and can be designed to generate both combined heat and power (CHP). Such plants can operate at about $22 \%$ efficiency producing about $600 \mathrm{kWh}$ of electricity per tonne of raw waste combustions. It is stated that emission from MSWC is low and with CHP, the overall efficiency of the plant may be raised to over $60 \%$. Table 18 provides a comparison between energy efficiency of fossil fuel and MSWC. In some Scandinavian countries, $25 \%$ of the energy consumption is met by MSWC. The energy recovery from combustion of municipal waste can help reducing the dependency on the use fossil fuels. Since the combustible part of municipal waste arises from renewable source, the $\mathrm{CO}_{2}$ produced does not add to net $\mathrm{CO}_{2}$ buildup in the atmosphere.

To reduce the significant impact of hazardous air pollutants (HAPs), such as benzene and vinyl chloride on human health and the environment and to mitigate the emissions of green house gases like methane, $\mathrm{CO} 2$ and problem of hazardous air pollutants from landfills many countries are adopting modern MSWC Technology. However, landfills with extensive lines, leachate collection, groundwater monitoring and methane recovery systems, should only be permitted in case of any constraints to go for MSWC technology. In general, countries have adopted integrated solid waste management with thrust on the following issues:

- Waste minimization

- Recovery and re-use of materials;

- Energy recovery;

- Disposal.

With various policy instruments and pricing initiatives, the situation in some countries has improved with achievements of material 
Table 18: MSWC Emissions Compared to Fossil Fuels (St Ouen, MSWCFacility, Paris).

Greenhouse Impact over 20 years

(Grams equivalent of $\mathrm{CO} 2$ per tonne of MSW burned for energy)

\begin{tabular}{lcc}
\hline Gas & Direct Emission & $\begin{array}{l}\text { Impact or savings } \\
\text { GreenhouseGas } \\
\text { compared to fossil } \\
\text { fuel }\end{array}$ \\
\hline $\mathrm{CO} 2$ & 405,000 & $-109,000$ \\
$\mathrm{CO}$ & 1,652 & -155 \\
$\mathrm{Nox}$ & 44,100 & 4,170 \\
$\mathrm{~N} 2 \mathrm{O}$ & 27,000 & $-97,650$ \\
\hline $\begin{array}{l}\text { Total greenhouse } \\
\text { gas reductions }\end{array}$ & $-220 \mathrm{~kg} \mathrm{CO} 2$ \\
$\begin{array}{l}\text { Atmospheric Acidifications } \\
\text { (Grams H+ per tonne of MSW burned for energy) }\end{array}$
\end{tabular}

Acid Gas Impact or Savings $\quad$ Compared to coal + Direct Emission

\begin{tabular}{lrr}
\hline NH3 & 0 & 0 \\
Nox & 3 & 3 \\
Sox & 20 & -84 \\
HCl & 6 & 6 \\
HF & 2 & 2 \\
\hline
\end{tabular}

Total acid gas reductions $\quad-73$ grams $\mathrm{H}^{+}$

* Negative numbers reflect emissions avoided by burning MSW rather than fossil fuel.

Source: L'ecobilan de l' incineration des dechets mehagers de l'usine du SYCTOM a Saint-Ouen, TIRU SA, Paris, France, Summer 1994.

recovery/recycling. MSWC and landfill disposal, demonstrated that an integrated waste management approach provides the solution to the treatment and disposal of MSW and MSWC has a significant role in energy recovery and recycling. Further, to reduce reliance on landfill disposal and to reap ecological benefits, there is continuous effort to improve the thermal conversion of MSW. Alternative technologies to the present MSWC with more recovery and/or recycling (through pre-treatment) to higher efficiency or even to better environmental performance than grate-fired MSWC are being developed and are evaluated in more depth. The techniques may either use two stage combustion, fluidized bed combustion, or gasification. However, further advances in pollution control technology and combustion efficiency may improve the economics of MSWC. This will help making MSWC as an important bioenergy sector.

To conclude, it appears that the amount of solid waste continues to increase at alarming rate and problems associated with it is becoming more and more serious. Solid waste, if not managed effectively, will adversely affect all the three components of the environment, namely air, water, and soil. The problem of solid waste management is more severe in cities due to the huge quantity and variety of waste, which warrants different management and disposal techniques. The task of managing MSW has been given to municipal corporations and other local bodies, which usually do not have adequate financial resources and trained staff to discharge the responsibility. A systematic and scientific approach to solid waste management, as explained above and proper implementation of legislative tools will go a long way in effective handling of solid wastes. As in several other sectors MSW sector should also be identified for providing fiscal and other tax incentives including appreciation by the authorities. This decision shall bring private sector participation and waste of present day shall be a resource for generating energy and large number of direct employment in the country. TERI (1999) reports that nearly $1000 \mathrm{MW}$ electric energy can be generated from urban and municipal waste and about $700 \mathrm{MW}$ from industrial wastes by applying waste management technologies in India. The National Bioenergy Board is evolving policy guidance and direction and Ministry of Non-conventional Energy Sources have initiated many programmes including biomethanation and other projects like pelletization, gasification, pyrolysis, incineration, and sanitary landfills in many states. It is opined that more demonstration projects and private sector participation with financial and fiscal incentives for waste disposal and management may encourage more investment which finally shall generate more employment, revenue and energy.

\section{REFERENCES}

Annon.: Clean energy from municipal solid waste: A vital bioenergy technology for the $21^{\text {st }}$ century. IEA Bioenergy Agreement Task XIV ETSU, Harewell, UK (1995).

Annon.: National Plastics Waste Management task Force Report, Union Ministry of Environment and Forests, August 1997, New Delhi, p. 15 (1997).

Bhide, A. D. and Sundaresan, B. B.: Street cleansing and waste storage and collection in India, pp. 139, In: Managing Solid Wastes in Developing Countries. J R Holmes Chichester (Ed.). John Wiley, NY, 304 pp.(1984).

Bhide, A.D. and Sundaresan, B. B.: Solid Waste Management 
in Developing Countries. Indian national Scientific Documentation Centre, New Delhi, 222 pp. (1983).

Bhoyar, R. V., Titus, S. K., Bhide, A. D. and Khanna, P.: Municipal and industrial solid waste management in India Journal of Indian Association of Environmental Management, 23: 53-641996

Bingemer, H. G. and Crutzen, P. J.: The production of methane from solid wastes Journal of Geophysical Research, 92: 2181-2187(1987)

Brown, K. A and Maunder, D. H.: Exploitation of landfills gas: a UK perspective. Waste Science Technology, 30 (12): 43 - 151(1994)

C.S.E.: Down to Earth. $31^{\text {st }}$ March, p 35. (2002)

C.S.E.: Down to Earth. $31^{\text {st }}$ March 2002. pp 56 (2002).

Datta, M.: Generation and control of leachate and landfill gas, p.90, In: Waste Disposal in Engineered Landfills. M. Datta (Ed.). F.F.Y. Enterprise New Delhi, 191pp. (1997).

Datta, M.: Waste Disposal in Engineered Landfills. Narosa Publishing House, New Delhi, 236 pp. (1997).

EPTRI: Status of Solid Waste Disposals in Metropolis. Environmental protection and training institute, Hyderabad, 46p. (1995).

GGTIE: Municipal solid waste mass burn: Clean energy from Municipal solid waste: A vital bioenergy technology for the $21^{\text {st }}$ century. IEA bioenergy Task, XIV, ETSU, Hawell, UK (1997).

INSDOC: Solid Waste Management in Developing Countries. Indian National Scientific Documentation Centre, New Delhi (1983).

Jain, S. C. and Garg, K. K.: Current Environmental Issues. The Environmental Society of India, Chandigarh (1997).

MoEF: National Environmental Management Programme. Ministry of Environment and Forests, New Delhi (1993).

MSWMB: Municipal solid waste Mass Burn. Green house gas technology information exchange. Jan. (1997).

Nanavaty, K P.: Plastics racing into the future. Keynote address delivered to the All India Plastics Manufacturers
Association, Madras, 25 th July, 1997, 15pp. (1997).

NEERI: Studies on health of refuse workers in Trivendrum (cited in the report of High power committee, p.13). Planning Commission, New Delhi, 1195, 100pp. (1971).

NIUA: Upgrading municipal services: Norms and financial implications. National Institute of Urban Affairs, New Delhi (1989).

ORG: Delivering and Financing Urban Services. Operation Research Group, Baroda (1989).

Rao, K. J. and Shantaram, M. V.: Soil pollution due to disposal of urban solid wastes at landfill sites, Hyderabad, India. Journal of Environment Protection, 16: 373 - 385 (1996).

Shivapullaiah, P.V.: Waste Characterisation, p.18, Table4, In: Waste Disposal in Engineered Landfills. M. Datta (Ed.). Narosa Publ. House, New Delhi (1977).

Sanon, C. G.: Working and living conditions of rag picker children: Findings of a research study: National Institute of Public Cooperation and Child Development, New Delhi (1986).

Sharma, V. K.,Beukering, P. V. and Ramaswamy, K.V.: The case of waste paper trade in India, p. 147 - 155, In: Conclusions and Policy Recommendations in International Trade and Recycling in Development Countries: . P. Van Beukering and V. K. Sharma (Eds.). Institute for Environmental Studies, Netherlands and Indira Gandhi Institute of Development Research Bombay 159 pp. (1996).

TERI.: An innovative bioprocess for stabilization of and energy recovery from solid waste: Tata Energy Research Institute, New Delhi $32 \mathrm{pp}$ (1996).

TERI.: Looking Back to Think Ahead - Green India 2047. TERI Publ., New Delhi(1998.).

TERI.: TERI Energy Data Directory and Yearbook. New Delhi, pp.135, (1999).

Venkateswaran, S.: The Wealth of Waste: Waste Pickers, Solid Waste and Urban Development. Friedrich Ebert Foundation, New Delhi. 96 pp. (1995). 